\title{
PENINGKATAN PENGETAHUAN DAN KETERAMPILAN PEMULIHAN GIZI BAGI KADER POSYANDU DAN IBU BALITA
}

\author{
Improvement of Nutrition Recovery Knowledges and Skills for Posyandu Cadres and Child \\ Mothers \\ Riyanto ${ }^{1}$, Choirun Nissa ${ }^{1}$ \\ ${ }^{1}$ Dosen Program Studi Ilmu Gizi STIKes Widya Cipta Husada Malang \\ Email : nissachoirun88@gmail.com
}

\begin{abstract}
ABSTRAK
Data Puskesmas Kepanjen Kabupaten Malang pada tahun 2017 khususnya di desa Cempokomulyo menunjukkan bahwa sebanyak 5,3\% balita mengalami gizi buruk dan 3,5\% mengalami gizi kurang. Sementara di desa Jatirejoyoso menunjukkan bahwa 3,4\% mengalami gizi kurang. Salah satu faktor yang mempengaruhi kejadian gizi buruk dan gizi kurang adalah rendahnya akses perawatan dan akses informasi bagi ibu balita dan kurangnya inisiatif dan keterampilan kader posyandu. Pemberian informasi, motivasi dan keterampilan yang dibutuhkan kader dan ibu balita dinilai sebagai salah satu langkah dalam pemulihan gizi. Tujuan kegiatan ini adalah peningkatan pengetahuan dan keterampilan kader dan ibu balita. Pelatihan gizi yang diberikan kepada kader dan ibu balita yaitu pengukuran status gizi, pemberian makan bayi dan anak, praktek pemberian ASI, deteksi tumbuh kembang dan penatalaksanaan pemulihan gizi di tingkat posyandu. Hasil kegiatan ini menunjukkan bahwa terdapat peningkatan pengetahuan kader dan ibu balita, pada saat pretest $10 \%$ pengetahuannya baik dan $5 \%$ pengetahuannya kurang dan pada saat posttest menjadi $85 \%$ pengetahuannya baik dan $15 \%$ cukup. Selain itu terjadi peningkatan keterampilan kader dan ibu balita, pada saat pretest $75 \%$ keterampilannya cukup dan $25 \%$ keterampilannya kurang dan pada saat posttest menjadi $90 \%$ keterampilannya baik dan $10 \%$ cukup. Dengan demikian dapat disimpulkan terdapat peningkatan pengetahuan dan keterampilan kader dan ibu balita menjadi sebagian besar baik. Kader posyandu dan ibu balita diharapkan dapat melaksanakan pemulihan gizi pada fase tindak lanjut di tingkat posyandu.
\end{abstract}

Kata kunci: pengetahuan, keterampilan, kader posyandu, ibu balita, pemulihan gizi

\section{Abstract}

Data from Kepanjen Health Center in Malang Regency in 2017, especially in the Cempokomulyo village, shows that $5.3 \%$ of children under five suffer from severe malnutrition and $3.5 \%$ suffer from malnutrition. While in the Jatirejoyoso village shows that $3.4 \%$ of toddlers experience malnutrition. One of the factors that influence the incidence of malnutrition is the lack of access to care and information for mothers of infants and the lack 
of initiative and skills of posyandu cadres. The provision of information, motivation and skills needed by cadres and mothers of children under five are considered as one step in nutrition recovery. The purpose of this activity is to increase the knowledge and skills of cadres and mothers of toddlers. Nutrition training was given to cadres and mothers of toddlers, namely measuring nutritional status, feeding infants and children, breastfeeding practices, detection of growth and development of nutrition recovery at the posyandu level. The results of this activity indicate that there is an increase in the knowledge of cadres and mothers of infants, at pretest $10 \%$ of knowledge is good and 5\% of knowledge is lacking and at the time of posttest it is $85 \%$ of knowledge is good and $15 \%$ is sufficient. In addition, there was an increase in the skills of cadres and mothers of toddlers, at pretest $75 \%$ of their skills were sufficient and $25 \%$ of their skills were lacking and at posttest they were $90 \%$ of good skills and $10 \%$ were sufficient. Thus it can be concluded that there is an increase in the knowledge and skills of cadres and mothers of toddlers to be mostly good. Posyandu cadres and toddler mothers are expected to be able to carry out nutritional recovery at the follow-up phase at the posyandu level.

Keywords: knowledges, skills, posyandu cadres, children under five mothers, nutrition recovery

\section{PENDAHULUAN}

Indonesia termasuk salah satu Negara yang masih dalam taraf perkembangan atau disebut dengan Negara berkembang (Asiyah, 2013). Tidak jauh berbeda dengan Negara berkembang lain di dunia, Indonesia juga sering menghadapi berbagai masalah salah satunya masalah kesehatan dan gizi. Ditinjau dari masalah kesehatan dan gizi, maka balita merupakan kelompok yang paling rentan mempunyai risiko menderita kelainan gizi yang bisa berujung pada kematian. Masa balita adalah masa lima tahun pertama dalam setiap kehidupan anak manusia. Suatu masa golden age yang sangat penting, terutama untuk pertumbuhan fisik (Ahira, 2010). Balita adalah masa yang disebut masa golden age atau masa keemasan anak. Pada masa ini,
90\% sel-sel otak individu tumbuh dan berkembang. Bila pada masa golden age anak-anak terabaikan, maka akan menjadi permasalahan bagi balita tersebut (Budirahardjo, 2011). Pada masa balita tersebut anak seharusnya banyak mendapatkan asupan gizi dalam jumlah besar, karena pada usia ini anak sedang mengalami masa perkembangan. Masalah ini tidak hanya menimbulkan masalah kesehatan, tetapi juga menurunkan kualitas sumber daya manusia.

Prevalensi gizi kurang pada balita (BB/U<-2SD) memberikan gambaran yang fluktuatif dari $18,4 \%$ pada tahun 2007 menurun menjadi $17,9 \%$ pada tahun 2010 kemudian meningkat lagi menjadi $19,6 \%$ pada tahun 2013. Data Puskesmas Kepanjen Kabupaten Malang pada tahun 2017 khususnya di desa Cempokomulyo 
menunjukkan bahwa $5,3 \%$ balita mengalami gizi buruk dan $3,5 \%$ mengalami gizi kurang. Sementara di desa menunjukkan bahwa $3,4 \%$ balita mengalami gizi buruk dan $3,4 \%$ mengalami gizi kurang. Prevalensi balita BGM (di bawah garis merah) di desa Cempokomulyo $(0,6 \%)$ dan Jatirejoyoso $(1,5 \%)$.

Masalah ini harus mendapatkan perhatian yang lebih dari berbagai pihak, seperti pemerintah pusat, pemerintah daerah, dinas sosial, dinas kesehatan maupun peran aktif masyarakat itu sendiri. Seperti yang kita ketahui jika melihat dari fakta yang ada kebanyakan masalah gizi kurang atau gizi buruk sering dialami oleh keluarga dengan tingkat perekonomian yang rendah atau yang biasa dikategorikan sebagai keluarga miskin, tingkat pengetahuan keluarga yang rendah, minimnya keterjangkauan akses informasi mengenai pelayanan kesehatan.

Apabila didiamkan masalah gizi menimbulkan masalah pembangunan di masa yang akan datang. Keterlambatan dalam memberikan pelayanan gizi akan berakibat kerusakan yang sulit atau bahkan tidak dapat ditolong. Dampak jangka pendek penderita gizi buruk meningkatkan angka morbiditas dan dampak jangka panjang adalah rendahnya kualitas sumber daya manusia.

Penanganan gizi buruk sangat terkait dengan strategi sebuah bangsa dalam menciptakan sumberdaya manusia yang sehat, cerdas dan produktif. Upaya peningkatan sumberdaya manusia yang berkualitas dimulai dengan cara penanganan pertumbuhan anak sebagai bagian dari keluarga dengan asupan gizi dan perawatan yang baik.

Guna mengantisipasi makin parahnya kondisi yang mungkin terjadi akibat kejadian gizi buruk, maka kami akan mengupayakan peran aktif kader posyandu dan ibu balita dalam pemulihan gizi melalui pelatihan peningkatan keterampilan dan pengetahuan kader dan ibu balita dalam pemulihan gizi sehingga diharapkan mampu memberikan hasil yang signifikan dalam menurunkan/mengurangi masalah gizi kurang dan kasus balita di bawah garis merah (BGM) yang masih ada.

\section{TUJUAN}

Tujuan kegiatan pelatihan ini adalah :

1. Peningkatan pengetahuan kader posyandu dan ibu balita dalam pemulihan gizi di tingkat posyandu

2. Peningkatan keterampilan kader posyandu dan ibu balita dalam pemulihan gizi di tingkat posyandu

\section{PELAKSANAAN}

Sebelum dilakukan pelatihan, terlebih dahulu mengidentifikasi balita yang gizi buruk atau kurang di desa jatirejoyoso dan cepokomulyo melalui data posyandu bulan Agustus 2018. Terdapat 18 balita gizi kurang di desa cepokomulyo pada posyandu bulan agustus 2018, dan terdapat 10 balita gizi kurang di desa jatirejoyoso pada posyandu bulan agustus 2018. Kegiatan pelatihan ini dilakukan dengan cara :

1. Penyuluhan kepada kader posyandu dan ibu balita tentang pemulihan gizi

2. Simulasi dan praktek kepada kader posyandu dan ibu balita tentang 
pemulihan gizi

Pelatihan ini dilaksanakan pada hari jumat dan sabtu tanggal 07 - 08 September 2018 bertempat di Balai Desa Cepokomulyo dan pada hari jumat dan sabtu tanggal 14 - 15 September 2018 bertempat di Balai Desa Jatirejoyoso dimulai pada pukul $08.00-12.00$ WIB. Kegiatan ini diikuti oleh 74 peserta terdiri dari 56 kader dan 18 ibu balita gizi kurang di Desa Cepokomulyo, sedangkan pelatihan di Desa Jatirejoyoso diikuti oleh 50 peserta terdiri dari 40 kader dan $10 \mathrm{ibu}$ balita gizi kurang. Materi yang disampaikan adalah sebagai berikut :

1. Penatalaksanaan pemulihan gizi di tingkat posyandu, dengan pemateri dokter/ahli gizi

2. Deteksi dini tumbuh kembang anak dengan pemateri bidan desa

3. Praktek pemberian ASI dengan pemateri konselor laktasi

4. Praktek pemberian makan bayi dan anak (PMBA) dengan pemateri ahli gizi

5. Praktek penggukuran status gizi (antropometri) dengan pemateri ahli gizi
Metode yang digunakan adalah: ceramah dan tanya jawab serta simulasi dan praktek, Rancangan evaluasi terhadap metode kegiatan ini adalah: 1) evaluasi pretest dan post test dengan memberikan daftar pertanyaan untuk mengetahui peningkatan pengetahuan dan keterampilan kader dan ibu balita sebelum dan sesudah diberikan pelatihan.

\section{HASIL DAN PEMBAHASAN}

Peserta pelatihan kader dan ibu balita di desa cepokomulyo dan desa jatirejoyoso seluruhnya adalah sebanyak 124 orang. Ealuasi keberhasilan dilakukan dengan memberikan daftar pertanyaan pretest dan posttest tentang pengetauan dan keterampilan. Hasil pretest terhadap pengetahuan kader dan ibu balita di kedua desa menunjukkan bahwa dari 25 pertanyaan diperoleh nilai skor minimal 11 dan skor maksimal 21. Pengetahuan peserta dikatakanbaik bila mempunyai skor $>/=20$, skor $15-19$ dikatakan cukup, dan skor < 15 dikatakan kurang (Khomsan, 1995). Hasil pretest dan posttest pengetahuan kader tampak pada gambar 1. 


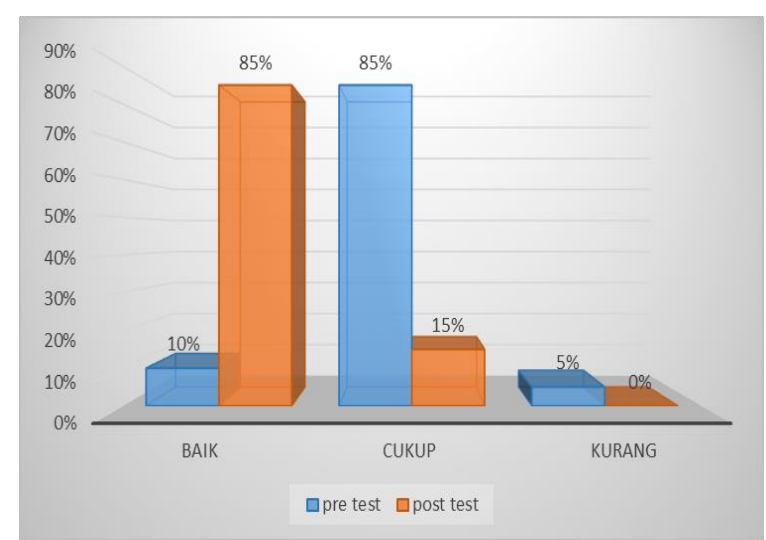

Gambar 1. Perbandingan hasil pretest dan posttest pada pengetahuan kader dan ibu balita

Skor pengetahuan kader dan ibu balita sebelum pelatihan $10 \%$ pengetahuannya baik dan $5 \%$ pengetahuannya kurang, sehingga sebagian besar peserta sebanyak $85 \%$ memiliki pengetahuan yang cukup. Hal ini dikarenakan sebagian kader sudah pernah mendapatkan penyuluhan kesehatan dari puskesmas maupun tenaga kesehatan lain, namun tidak demikian halnya dengan sebagian kecil ibu balita yang memiliki akses kurang terhadap informasi karena kurangnya partisipasi posyandu. Hasil posttest pengetahuan menunjukkan bahwa dari 25 pertanyaan yang diberikan, diperoleh nilai maksimal 25 dan nilai minimal 16, yaitu sebanyak $85 \%$ pengetahuannya baik dan $15 \%$ cukup. Hal ini dapat disimpulkan bahwa terdapat peningkatan pengetahuan peserta yang dikategorikan sebagian tergolong baik. Peningkatan pengetahuan kader dan ibu balita terjadi karena diberikan penyuluhan yang bermanfaat dengan kebutuhan responden saat ini. Hal ini sejalan dengan penelitian yang dilakukan oleh Hamida, dkk (2012) bahwa terjadi peningkatan pengetahuan responden setelah diberikan penyuluhan dengan metode ceramah.

Skor keterampilan kader dan ibu balita, pada saat pretest $75 \%$ keterampilannya cukup dan $25 \%$ keterampilannya kurang. Hal ini mungkin disebabkan kader dan ibu balita sudah terbiasa melaksanakan pelayanan posyandu namun jarang mendapat pelatihan yang dapat meningkatkan keterampilannya. Hasil posttest menunjukkan bahwa sebanyak $90 \%$ kader dan ibu balita keterampilannya baik dan $10 \%$ cukup sehingga dapat disimpulkan terjadi peningkatan ketrampilan yang dikategorikan sebagian besar baik.

Hasil pretest dan posttest keterampilan kader dapat dilihat pada gambar 2 . 


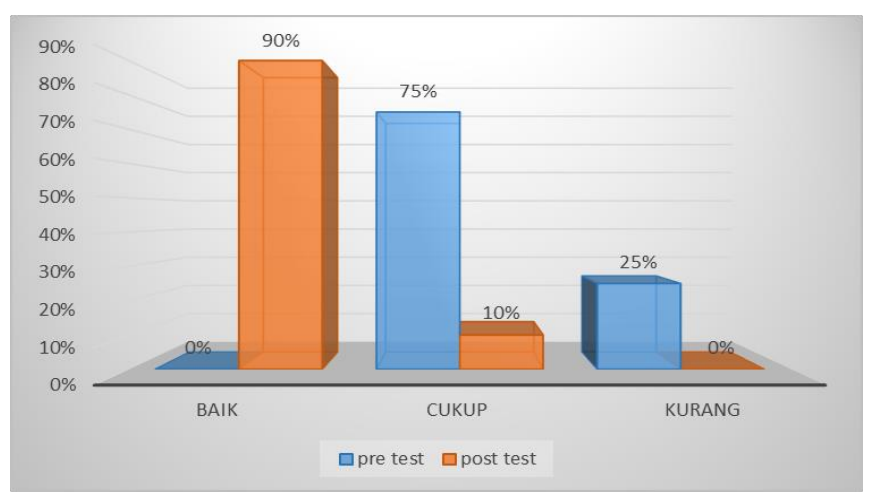

Gambar 2. Perbandingan hasil pretest dan posttest pada keterampilan kader dan ibu balita

Berdasarkan Khomsan (1995), seseorang dikatakan berketerampilan baik apabila dapat melakukan tindakan tanpa bantuan, dikatakan cukup apabila dapat melakukan tindakan dengan sedikit bantuan dan dikatakan keterampilannya kurang apabila tidak dapat melakukan tindakan dengan bantuan. Peningkatan keterampilan karena diberikan pelatihan dengan demonstrasi langsung. Hal ini sejalan dengan penelitian yang dilakukan oleh Laraeni, dkk (2014) dan Rahayu, dkk (2009) bahwa terdapat peningkatkan pengetahuan dan keterampilan kader setelah dilakukan penyuluhan dengan ceramah dan demonstrasi. Menurut Herijulianti, dkl (2002) metode yang digunakan dalam mengembangkan sikap atau perilaku adalah demonstrasi dengan melibatkan peserta di dalamnya. Simamora (2009) mengatakan bahwa kelebihan metode demonstrasi adalah membantu peserta didik dalam memahami dengan jelas alur suatu proses serta dapat menimbulkan kesan dan pengalaman yang melekat dalam peserta didik.

Peningkatan pengetahuan ibu kader dan balita akan mendukung sikapnya terhadap perubahan, sehingga dapat memotivasi perubahan perilaku/keterampilan kader dan ibu balita. Hal ini didukung oleh Notoatmodjo (2010) yang menyatakan bahwa perilaku yang didasari oleh pengetahuan akan lebih langgeng daripada perilaku yang tidak didasari oleh pengetahuan.

\section{KESIMPULAN}

1. Skor pengetahuan kader dan ibu balita sebelum pelatihan $10 \%$ pengetahuannya baik dan 5\% pengetahuannya kurang dan pada saat posttest menjadi $85 \%$ pengetahuannya baik dan $15 \%$ cukup

2. Terjadi peningkatan pengetahuan yang dikategorikan sebagiantergolongbaik

3. Skor keterampilan kader dan ibu balita, pada saat pretest $75 \%$ keterampilannya cukup dan $25 \%$ keterampilannya kurang dan pada saat posttest menjadi $90 \%$ keterampilannya baik dan $10 \%$ cukup.

4. Terjadi peningkatan ketrampilan yang dikategorikan sebagian besarbaik.

\section{SARAN}

1. Kader posyandu dan ibu balita diharapkan dapat melaksanakan 
pemulihan gizi pada fase tindak lanjut di tingkat posyandu.

2. Informasi tentang balita gizi kurang diharapkan dapat dijadikan sebagai program kebijakan bagi para perencana kesehatan di tingkat daerah maupun pusat.

\section{DAFTAR PUSTAKA}

Ahira.D, 2010, Pertumbuhan Fisik Balita [serial online],. Diakses: 2 Juni 2017, dari http://www.ahira pertumbuhan fisik balita.htp

Aisyah Tarya Utari Putri, Yuniati, Evi Fitriany. 2013. Hubungan Anemia pada Ibu Hamil dengan Kejadian BBLR Di RSUD Abdul Wahab Sjahranie Samarinda Tahun 2013. Jurnal Program Studi Pendidikan Dokter Fakultas Kedokteran Universitas Mulawarman. No.11 tahun 2013. https://anzdoc.com/hubungananemia-pada-ibu-hamildengan-kejadian-bblr-di-rsudhtml

Budirahardjo. 2011. Golden Age. Jakarta

Hamida Khairuna., Zulaekah Siti, Mutalazimah. 2012. Penyuluhan gizi dengan media komik untuk meningkatkan pengetahuan tentang keamanan makanan jajanan. Jurnal Kesehatan Masyarakat, 8 (1): 67 73.

https://journal.unnes.ac.id/nju/i ndex.php/kemas/article/view/2 261/2698

Herijulianti, E, Indriani, T. S, Artini S,
2002. Pendidikan Kesehatan Gigi. Kedokteran EGC: Jakarta

Khomsan. A. 1995. Pengukuran

Pengetahuan. Bandung: IPB Press.

Laraeni Yuli, Wiratni Afni. 2014.

Pengaruh Penyegaran Kader

TerhadapPengetahuan dan

Keterampilan kader Posyandu menggunakan dacin, Media Bina Ilmiah, 8 (4): 44. http://www.lpsdimataram.com/ phocadownload/Juli-2014/7 pengaruh $\% 20$ penyegaran $\% 20 \mathrm{k}$ ader\%20terhadap\%20pengetah uan\%20dan\%20keterampilan\% 20kader-yuli\%20laraeni.pdf $\underline{52}$

Notoatmodjo, Soekidjo. 2010. Ilmu Perilaku Kesehatan. Jakarta : Rineka Cipta

Puskesmas Kepanjen Kabupaten Malang. 2017. Data Dasar Gizi Puskesmas Kepanjen Kabupaten Malang Tahun 2017.

Rahayu, Yayuk,S. 2009. Pengaruh Pelatihan (Metode Ceramah dan Demonstrasi) Terhadap Pengetahuan dan Keterampilan Kader Mengisi KMS dan menginterpretasikan Hasil Penimbangan balita. Skripsi. Politeknik Kesehatan Depkes Mataram, NTB.

Simamora, H, Raymond. Buku ajar pendidikan dalam keperawatan. Jakarta : Buku Kedokteran EGC, 2009. 